\title{
Screening tests of the protein quality of grain legumes for poultry production
}

\author{
BY K. G. WIRYAWAN AND J. G. DINGLE \\ Department of Animal Production, University of Queensland, Gatton, 4343 Australia
}

(Received 25 November 1994 - Accepted 20 February 1995)

\begin{abstract}
Three screening tests for protein quality, modified limiting amino acid score (MLAAS), net weight gain (NWG) and net protein ratio (NPR), were compared. Two experiments using young broiler chickens were conducted in a temperature-controlled room at $28.5 \pm 0.5^{\circ}$ with no adaptation to cages and diets, or at $31 \pm 0.5^{\circ}$ with $2 \mathrm{~d}$ adaptation to cages and diets. Nine isoenergetic diets containing nominally $100 \mathrm{~g}$ crude protein/kg supplied by legume meals and one isoenergetic $\mathrm{N}$-free diet were randomly allocated to chicks in single cages in each side of a four-tier battery brooder. Each dietary treatment had eight replicates. The chickens had access ad lib. to diet and drinking water throughout a $14 \mathrm{~d}$ observation period. Body weight and feed were measured at the start on day 7 and at the end on day 21 . The results indicated that keeping the chickens at $31 \pm 0.5^{\circ}$ and giving them a $2 \mathrm{~d}$ adaptation period decreased the variability of chickens' responses to each treatment. MLAAS, NWG and NPR methods could distinguish legume proteins of high, medium and low feed values. MLAAS correlated well with NWG $(r 0.90 ; P<0.001)$ and NPR $(r 0.78 ; P<0.01)$ in evaluating the protein quality of grain legumes used as sole sources of protein for meat chickens. However, MLAAS did not predict the exact order of NWG and NPR. Growth was limited because dietary methionine, the first limiting amino acid, provided only $27.6-55.2 \%$ of the recommended proportion in the protein. Although the results should be interpreted cautiously since a small sample size was used, it was concluded that the MLAAS calculation could be used as a reasonable estimate of the relative protein quality of most grain legumes, but that NWG and NPR were better methods as they detected limiting factors other than limiting amino acids in raw and processed legumes.
\end{abstract}

Protein quality: Amino acid score: Legumes: Broiler chickens

Conventional sources of protein for animals, such as fish-meals and soyabean meals, are often in short supply and expensive. Other grain legumes offer an alternative to fatextracted soyabean meal (SBM) because they have a similar amino acid profile (Ravindran \& Blair, 1992) and are often cheaper. Although grain legumes in Australia are grown seasonally for human consumption, spreading production throughout the year (Davies, 1989; Food and Agriculture Organization, 1989) would result in increased amounts of legumes becoming available for stockfeed. At the present time, however, the utilization of grain legumes as sources of protein for poultry is limited due to uncertainty about their nutritional quality. The variation in quality of grain legumes appears to be a combination of variable protein quality and variable amounts of antinutritional factors (ANF). The availability of a rapid protein-quality test would give feed manufacturers a greater ability to select and use grain legumes and hence build confidence in the market.

Johnson \& Eason (1990) showed that the inclusion of 80,140 and $200 \mathrm{~g} / \mathrm{kg}$ of field pea (Pisum sativum), lupin (Lupinus angustifolius) or chickpea (Cicer arietinum) in a sorghumand wheat-based diet did not affect the performance of broiler chickens but the same levels of narbon beans (Vicia narbonensis) significantly depressed growth. The discrepancy in 
results between the legumes may have been due to variability of activity of ANF such as protease inhibitors, lectins or tannins, and/or to the presence of non-digestible carbohydrate in some species or cultivars, leading to reduced digestibility, possibly because of low accessibility of the legume protein to digestive enzymes (Gatel, 1994; Liener, 1994). Although heat treatment can reduce the activity of ANF in grain legumes (van der Poel, 1990; Anderson-Hafermann et al. 1992; Singh et al. 1993), such treatments will probably increase costs for the feed miller, and excessive heating could reduce the availability of amino acids (Rani \& Hira, 1993; van Barneveld et al. 1993). Because of the variation of both raw and processed material, each batch of grain legume probably should be tested for its nutritional quality.

Dingle (1972) identified sixty-one in vivo and thirty-three in vitro methods for the evaluation of protein quality. For the purpose of identifying a screening test which could be used to rank the protein quality of various sources of protein, limiting amino acid score (LAAS; Bender, 1958), growth rate or net weight gain (NWG), and net protein ratio (NPR; Bender \& Doell, 1957), were investigated because of their simplicity and short test time. In protein-quality tests, diets containing $100 \mathrm{~g}$ protein $/ \mathrm{kg}$ are usually applied, since more consistent and discriminating results have been obtained (Bressani, 1977).

The objectives of the present study were to develop and evaluate the above proteinquality test methods for their rapidity and repeatability in estimating the protein quality of some grain legumes for poultry production.

\section{MATERIALS AND METHODS}

Two experiments were conducted to compare three methods for the evaluation of protein quality of grain legumes for poultry production.

\section{Proximate analysis}

The proximate compositions of black gram (Phaseolus mungo), chickpeas (cv. Desi and cv. Kaniva), faba bean (Vicia faba), field pea, green gram (Phaseolus aureus), lupin, pigeon pea (Cajanus cajan), and solvent-extracted SBM were determined according to standard procedures (Association of Official Analytical Chemists (AOAC), 1984). Heat stable $\alpha$ amylase (EC 3.2.1.1; AOAC approval number A3306; Sigma Chemical Co., St. Louis, MO, USA) was used in the crude fibre, acid-detergent fibre (ADF) and neutral-detergent fibre (NDF) determinations.

\section{Experiment 1}

Diets. The SBM and all raw legumes were obtained from local (Queensland, Australia) suppliers. They were hand-cleaned to remove wastes, then ground to pass a $1 \mathrm{~mm}$ screen. As the sole source of dietary protein, each of the legume meals contributed $100 \mathrm{~g}$ dietary protein $/ \mathrm{kg}$ calculated from published values. Maize starch, dicalcium phosphate, limestone, and vitamin and mineral premixes were added to each diet according to least-cost formulation (User Friendly Feed Formulation, 1986). All diets were made isoenergetic (13 MJ metabolizable energy (ME) $/ \mathrm{kg}$ ) by adding sunflower-seed oil and were made equal in fibre content by adding rice-hull meal (Tables 1 and 2). Ingredients for each diet were mixed in a single batch for approximately $25 \mathrm{~min}$.

Chickens and experimental procedures. Eighty unsexed commercial broiler chickens were used in the assay. During days 1-6 post hatching the chickens were kept in a group and fed on a commercial starter diet, and on day 7 they were allocated to the dietary treatments (Table 1). The chickens were housed individually in a four-tier double-sided battery brooder. Each treatment had eight replicates and two replicates of each treatment were distributed randomly in each tier. The room temperature was maintained between 28 and 


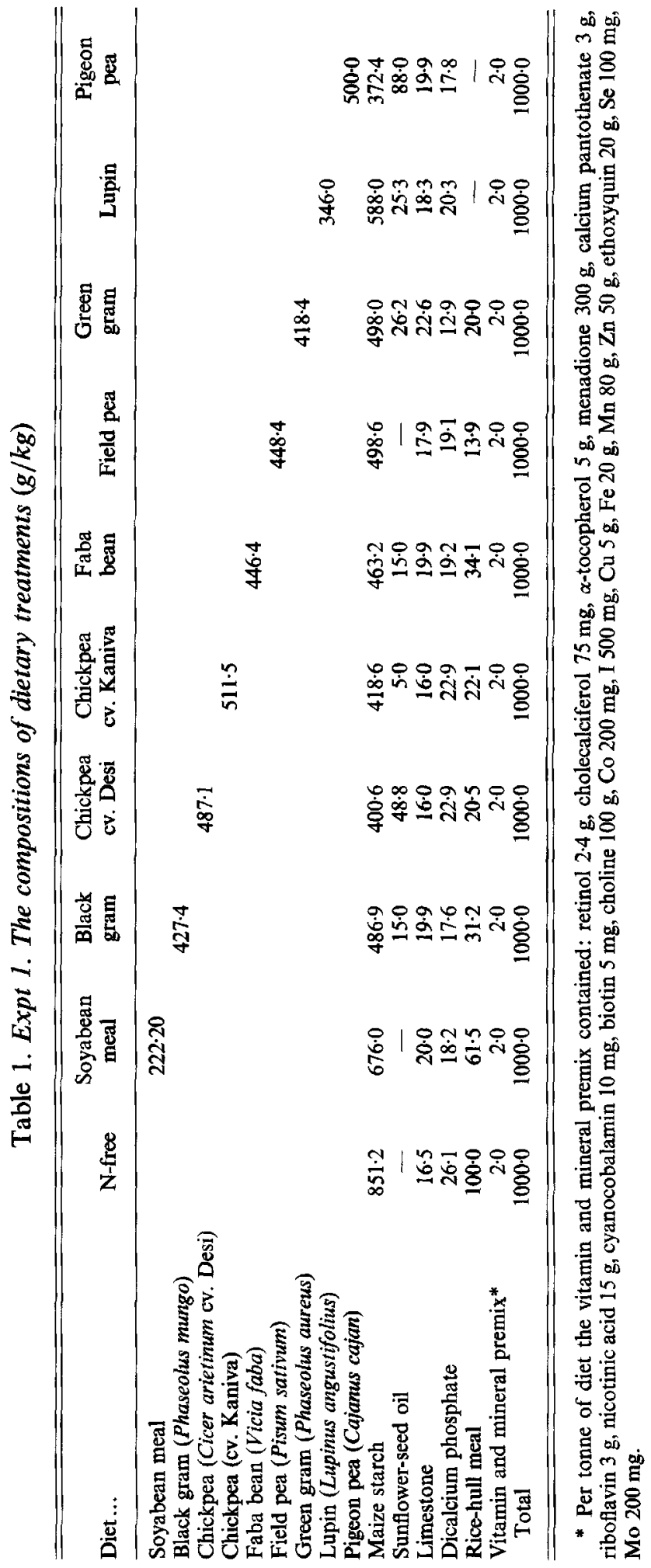


K. G. WIRYAWAN AND J. G. DINGLE

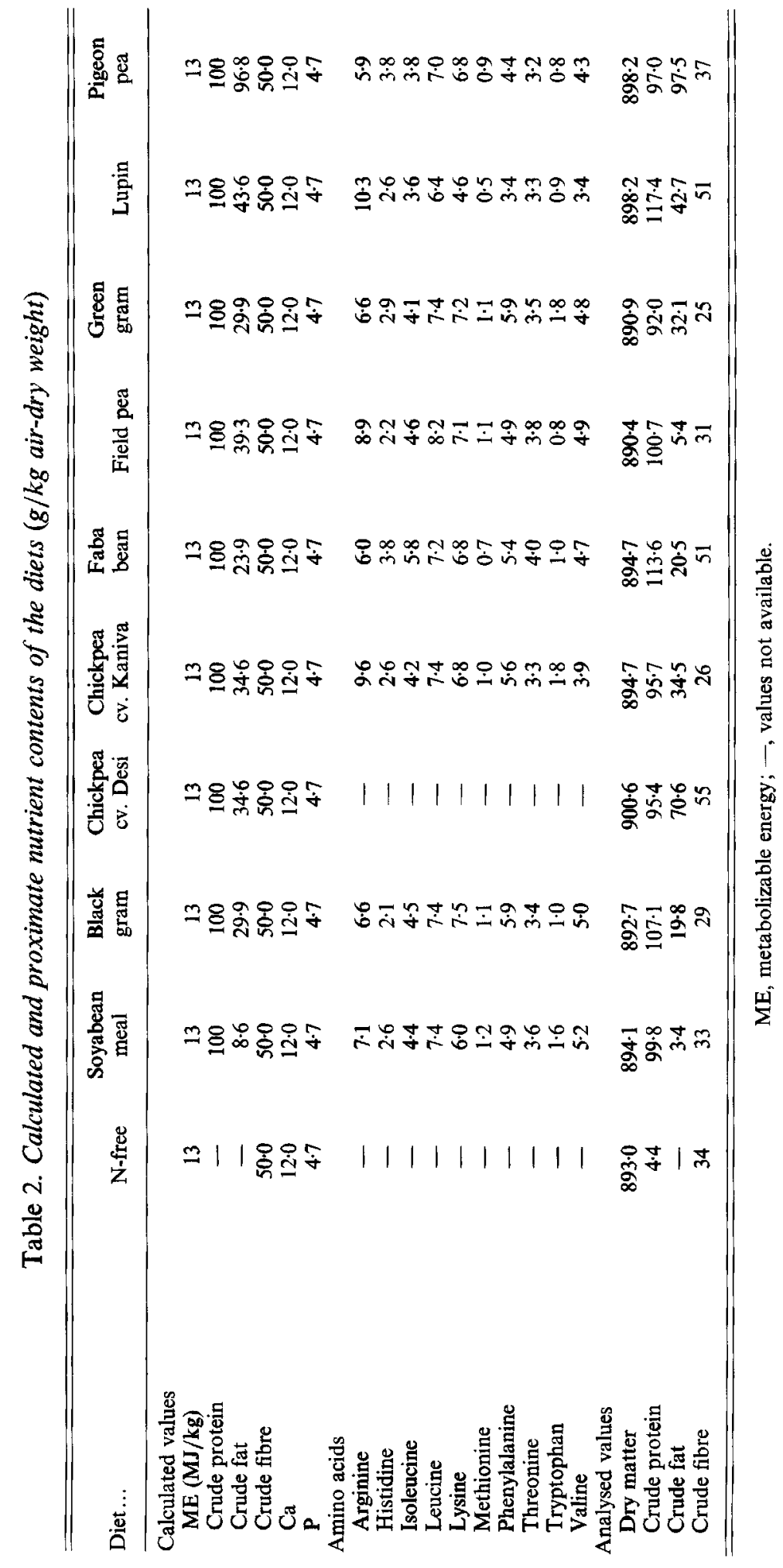


$29^{\circ}$ and light was provided continuously. The chickens had access $a d$ lib. to feed and water for $14 \mathrm{~d}$. They were weighed at $7 \mathrm{~d}$ and $21 \mathrm{~d}$ after an overnight fast. Feed allowance, feed refusal and feed spills were measured.

The chickens' response to dietary protein was assessed in terms of NWG and NPR. NPR was calculated as (weight gain of the chickens fed on the test diet + weight loss of the chickens fed on the protein-free diet) divided by protein intake (Bender \& Doell, 1957). The modified limiting amino acid score (MLAAS) used in these trials was based on the lowest ratios of $\mathrm{mg}$ amino acid/g protein in the legume to $\mathrm{mg}$ of the same amino acid/g dietary protein allowance recommended by the National Research Council (1994), as proposed by Dingle \& Wiryawan (1994). The protein quality of grain legumes was ranked according to the descending value of their MLAAS, NWG and NPR scores. The distribution of the scores was further ranked into high, medium and low.

\section{Experiment 2}

This was a repeat of the first experiment with the following modifications: (a) the analysed protein content of each legume was used to calculate dietary protein (Table 3); (b) room temperature was increased to $31 \pm 0 \cdot 5^{\circ}$; (c) the chickens were placed in the cages and fed on a mixture of commercial and SBM diet $(3: 1, w / w)$ for $2 \mathrm{~d}$ before the start of the feeding trial, and (d) body weights were measured at day 14 also.

\section{Statistical analysis}

Statistically significant differences between the mean NWG, protein intake and NPR value of chickens given each dietary treatment, and for each experiment, were calculated by using the Statistical Analysis Systems procedure General Linear Model (SAS Institute, Inc. 1990).

\section{RESULTS AND DISCUSSION}

The proximate compositions of the legumes tested showed that their protein contents were between 180 and $460 \mathrm{~g} / \mathrm{kg}$ (Table 3). These were within the range of published values (Evans, 1985; Ravindran \& Blair, 1992). Apart from SBM, lupin contained the most and pigeon pea the least protein (Table 4). Because approximately equal amounts of protein were included in the test diets, the extent to which the amino acid composition of each protein coincided with the chickens' requirements determined the protein quality score using the MLAAS calculation.

Fibre content, in terms of crude fibre, NDF or ADF, also varied between legumes. Lupin had the highest and chickpea (cv. Kaniva) the lowest. It is also worth noting that grain legumes are a source of dietary carbohydrate energy since they contain significant amounts of N-free extract (NFE), mainly sugars and starch (Reddy et al. 1984). Most of the raw legumes analysed did not contain appreciable amounts of lipid. Chickpeas and lupin however, contained $40-60 \mathrm{~g}$ lipid $/ \mathrm{kg}$ (Table 3 ). The significance of legume lipid and NFE in providing energy for chickens has not been elucidated. It is possible that their ME value may vary inversely with their concentration of non-starch polysaccharides, as with cereals (Annison, 1991).

There were some differences between calculated and analysed values of dietary protein, fibre and fat for Expt. 1. These differences were small except in the case of crude fat in chickpea (cv. Desi) and field pea. In the case of protein content, chickpea was about $15 \%$ lower, while faba bean and lupin were about $15 \%$ higher than the calculated values. The analysed protein content of the non-protein diet may be accounted for by residual amounts of $\mathrm{N}$ in maize starch and the rice-hull meal.

NWG and protein intake of chickens given different legumes in Expt. 2 were significantly $(P<0.001)$ higher than those in Expt. 1, indicating that the modified experimental 


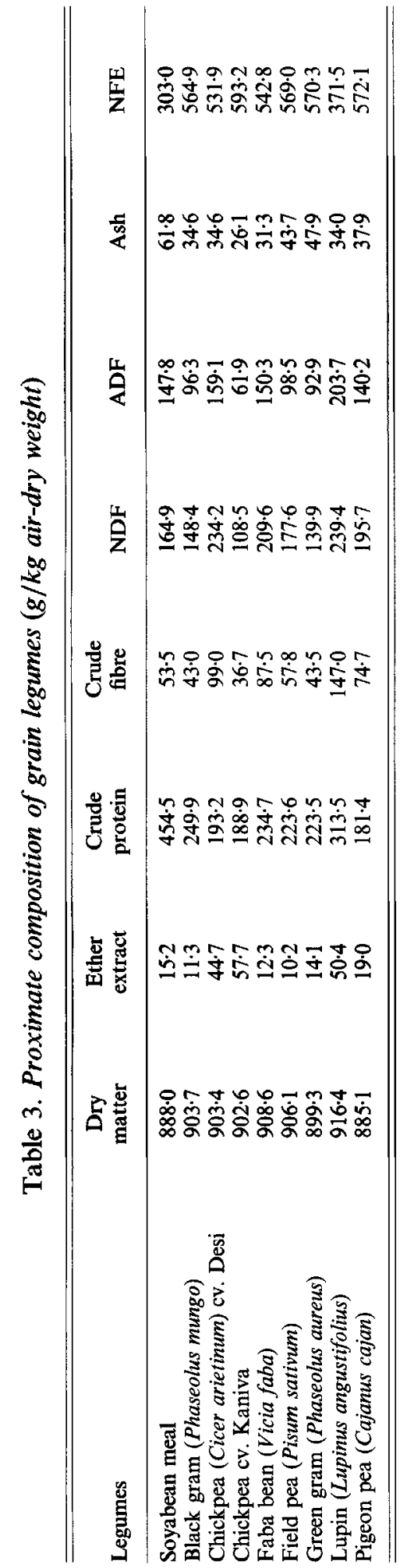

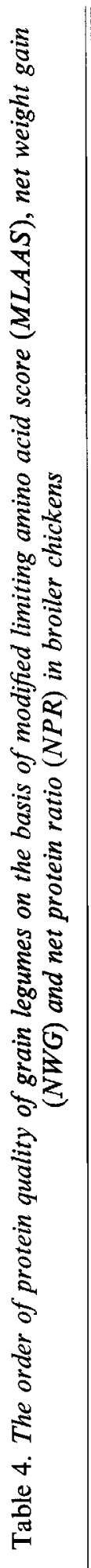

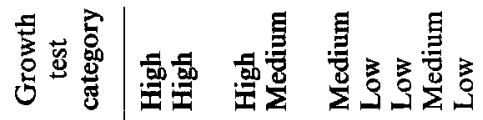

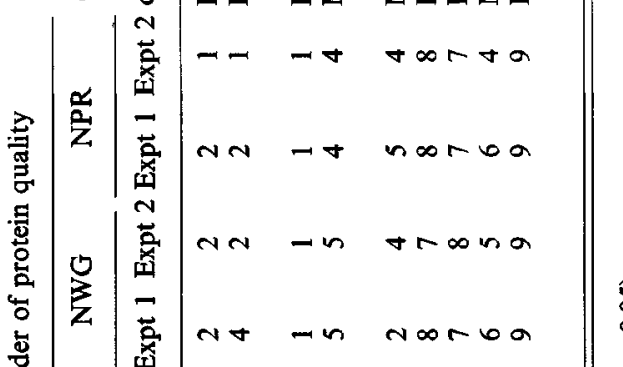

$\sum_{j}-N$ nt nor $n a$

范

离

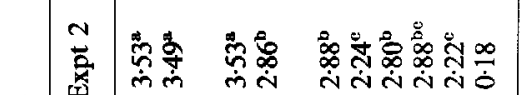

帘

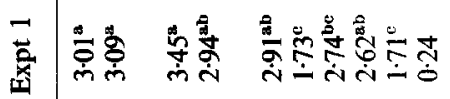

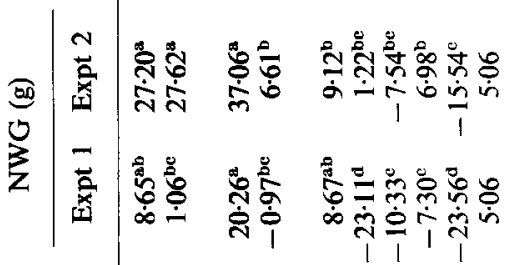

节文

के

这

क 3

$\stackrel{\square}{0}$

를

品

总.

영

音

|

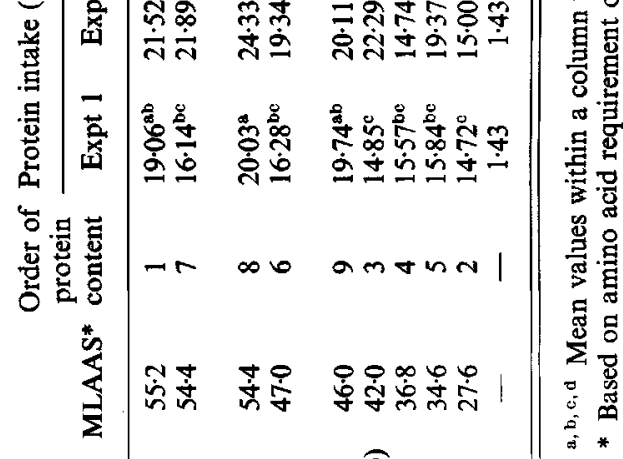

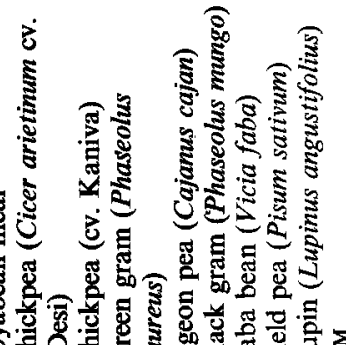

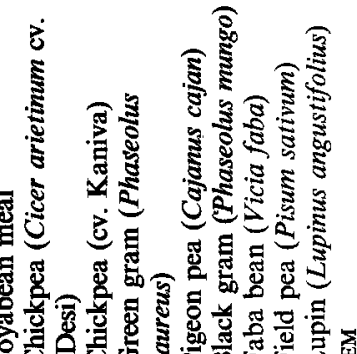


conditions improved responses of chickens to the dietary proteins. The small increase in room temperature may have been partly responsible for the difference. Many chickens in Expt. 1 showed signs of discomfort (chirping and shivering) throughout the trial, indicating that the temperature of $28.5 \pm 0.5^{\circ}$ was not warm enough for chickens aged $1-3$ weeks. The introduction of dietary treatments, at the same time as the chickens were placed in the single-cage environment, caused some chickens to stop eating for several days, resulting in a low total feed intake which caused a reduced weight gain. A 2 d period of adaptation to the cages and the mash diet was justifiable since the chickens accepted the experimental mash diets immediately. The limitation of using mash diets was a relatively larger amount of feed spill, especially with diets incorporating a large amount of starch, compared with a crumbed diet. Careful recovery of feed spill increased the precision of measuring feed intake.

There was no significant difference between blocks, indicating that, under the conditions of our studies, tier height and differences in light intensity in the room did not affect the chickens' performances.

Duncan's multiple range test showed that the NWG for chickens given chickpea (cv. Kaniva) in Expt. 1, or both chickpea diets in Expt. 2, were similar to those of chickens given SBM and significantly $(P<0.05)$ higher than the NWG of chickens given the other legumes (Table 4). This indicated that the nutritive values of SBM and chickpeas were superior to those of other selected legumes.

The greater NWG of chicks given cv. Kaniva than those given cv. Desi could partly be explained by the lower fibre content of cv. Kaniva ( $2 \cdot 6 v .5 \cdot 5 \%$, Table 2$)$. The MLAAS, NWG and NPR values of chickens fed on SBM and chickpea cv. Kaniva were not significantly different, indicating that raw cv. Kaniva chickpeas may not have contained ANF. It is possible, however, that there were ANF in both chickpeas and SBM. Other possible reasons for less than maximal growth of chickens fed on SBM are that overheating may reduce the availability of certain amino acids in SBM (Rani \& Hira, 1993; van Barneveld et al. 1993), and chickens given SBM as the sole source of protein may not grow as well as chickens fed on a combination of SBM and another source of protein (Irish \& Balnave, 1993).

The low NWG from feeding legumes other than chickpeas and SBM, and the severe weight losses of chickens given lupin, were apparently due to a combination of insufficient intake of sulphur-containing amino acids, due to their limiting amounts in the diets, and to low feed intake possibly associated with the sticky nature of the lupin diet. ANF may also have been responsible for some of the weight loss.

Fig. 1 indicates the amino acids that were well supplied and those that were in short supply for chickens' requirements from chickpea (cv. Kaniva) and lupin.

The amounts of most amino acids supplied in both experiments fulfilled the birds' requirements at $100 \mathrm{~g}$ protein $/ \mathrm{kg}$. However, methionine, the first limiting amino acid in all diets, supplied only $27 \cdot 6-55 \cdot 2 \%$ of the requirement. Lupin, especially, was not only very deficient in methionine but also contained insufficient lysine. Supplementation of lupin with both methionine and lysine improves its protein quality (Sarwar et al. 1978; Perez-Alba et al. 1990). Threonine is the next limiting amino acid for both of these legumes.

There were negative correlations between the protein contents of the legumes and their MLAAS $(r-0.80 ; P<0.01)$, NWG $(r-0.87 ; P<0.01)$ and NPR $(r-0.76 ; P<0.01)$ values. These indicate that the protein quality of unprocessed legumes with a high protein content is poorer than that of those with a lower protein content. Grain legumes with a high protein content have been found to be associated with relatively low concentrations of lysine, sulphur amino acids, tryptophan and threonine (Mosse, 1990). The legumes with moderate protein concentrations were sources of medium quality protein.

The MLAAS values were positively correlated with NWG values and NPR values. The 


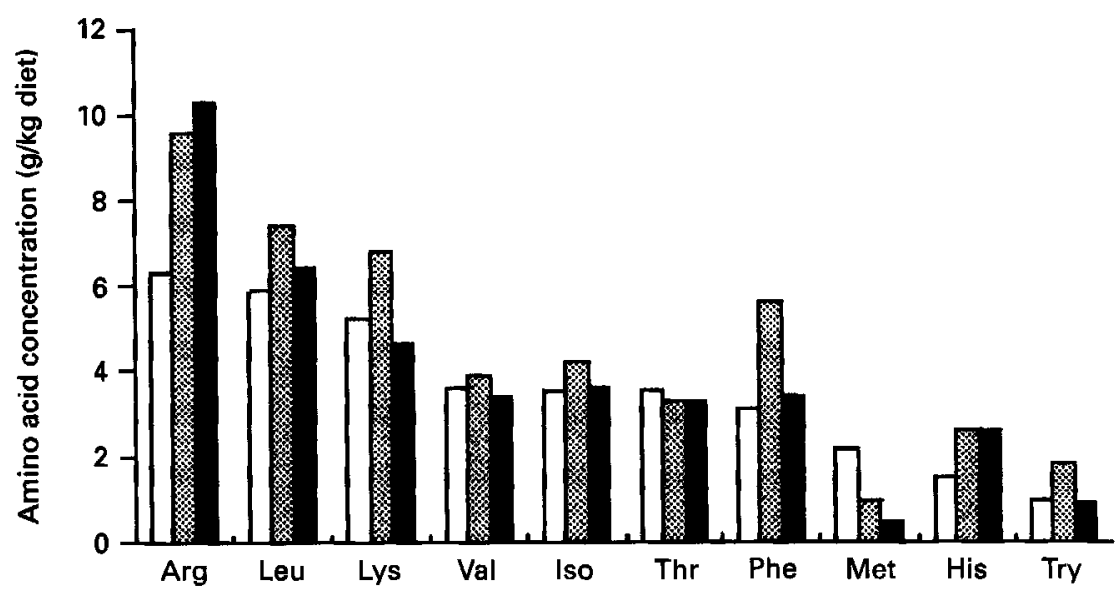

Fig. 1. Concentrations of amino acids ( $\mathrm{g} / \mathrm{kg}$ diet) required by chickens $(\square)$ and those provided by diets containing chickpea (Cicer arietinum cv. Kaniva; 0 ) or lupin (Lupinus angustifolius; ${ }^{\text {a }}$ ) a level providing $100 \mathrm{~g}$ protein $/ \mathrm{kg}$ diet.

correlation coefficients were 0.74 and $0.75(P<0.002)$ respectively in Expt 1 and $0.90(P<$ $0.001)$ and $0.78(P<0.01)$ respectively in Expt 2 . These suggest that the protein quality of most grain legumes for broiler chickens could be reasonably estimated from their analysed amino acid content relative to the dietary amino acid requirement of the chickens.

Although the protein quality of some grain legumes, when based on NPR value, was in most cases of a similar order to their theoretical value (MLAAS), in other cases their order was higher or lower than expected (Table 4). The three protein quality indices distinguished three low, three medium and three high nutritional value legumes. The categories designated for black gram and field pea by MLAAS were reversed in the NWG and NPR scores (Table 4).

MLAAS and NPR methods showed consistent results for SBM, chickpeas, faba bean, green gram and lupin. However, the range of NPR values was much narrower than the range of MLAAS values (1.6:1 v. 2:1, the highest to the lowest) and therefore NPR may not be useful as MLAAS for grading feed proteins into high, medium and low values. However, these results should be interpreted with caution because only small sample sizes were used.

In conclusion, the rapid screening tests MLAAS, NWG and NPR could be used to grade grain legumes into high, medium and low quality. On the basis of NPR values the two chickpea varieties and SBM were grouped together into sources of high quality protein; green gram, pigeon pea and field pea were sources of medium quality protein and black gram, faba bean and lupin were sources of low quality protein. In categorizing the protein value of grain legumes into high, medium or low these rapid tests gave reasonably repeatable results in two experiments. Any of these is probably an adequate basis for purchasing and formulating decisions. The correlation between the three screening tests was high, therefore the use of the MLAAS, the simplest and quickest method, employing calculating and no growth test, was a reasonable estimate of protein quality for most grain legumes.

The research was supported by the Egg Industry Research and Development Council of Australia. Mr F. Gorbacz is thanked for his technical assistance. 


\section{REFERENCES}

Anderson-Hafermann, J. C., Zhang, Y. \& Parson, C. M. (1992). Effect of heating on nutritional quality of conventional and Kunitz trypsin inhibitor-free soyabeans. Poultry Science 71, 1700-1709.

Annison, G. (1991). The relationship between the level of soluble non-starch polysaccharides and the apparent metabolisable energy of wheat assayed in broiler chickens. Journal of Agricultural and Food Chemistry 39 , 1252-1256.

Association of Official Analytical Chemists (1984). Official Methods of Analysis, 14th ed. Washington, DC: AOAC.

Bender, A. E. (1958). The amino-acid standards for calculating chemical score. Proceedings of Nutrition Society 17, xxxix.

Bender, A. E. \& Doell, B. H. (1957). Biological evaluation of proteins: a new aspect. British Journal of Nutrition 11, 140-148.

Bressani, R. (1977). Human assays and applications. In Evaluation of Proteins for Humans pp. 81-118 [C. E. Bodwell, editor]. Westport; Connecticut: AVI Publishing Company, Inc.

Davies, R. L. (1989). Advances in grain legume utilization for pig production. In Recent Advances in Animal Nutrition in Australia, pp. 123-130 [D. J. Farrell, editor]. Armidale, NSW: UNE.

Dingle, J. G. (1972). Method of measuring dietary protein quality for chicken. Proceedings 1972 Australian Poultry Science Convention, New Zealand Branch, World Poultry Science Association, Auckland, pp. 335-370.

Dingle, J. G. \& Wiryawan, K. G. (1994). Protein value of grain legumes. Proceedings of the Queensland Poultry Science Symposium 3, 73-82.

Evans, M. (1985). Nutritional Composition of Feedstuffs for Pigs and Poultry, p. 92. Brisbane: Queensland Department of Primary Industries.

Food and Agriculture Organization (1989). Quarterly Bulletin of Statistics, vol. 2, no. 4, pp. 51-53. Rome: Food and Agriculture Organization.

Gatel, F. (1994). Protein quality of legume seeds for non-ruminant animals: a literature review. Animal Feed Science and Technology 45, 317-348.

Irish, G. G. \& Balnave, D. (1993). Soybean meal as the sole source protein concentrate in broiler diets and the effect of additional protein concentrates. Proceedings of the Australian Poultry Science Symposium 5, 70.

Johnson, R. J. \& Eason, P. J. (1990). Effect of dietary inclusion of field pea lupin, narbon beans and chickpea on the growth performance of broiler chickens. Proceedings of the Australian Poultry Science Symposium 2 , 96-99.

Liener, I. E. (1994). Implication of anti-nutritional components of soybean foods. Critical Reviews in Food Science and Nutrition 34, 31-67.

Mosse, J. (1990). Acides amines de 16 cereales et proteagineux: variations et cles du calcul de la composition en fonction du taux d'azote des grain(e)s. Consequences nutritionelles (Amino acids in sixteen cereals and protein grain: Variation and prediction of composition from nitrogen content of the grain. Nutritional consequences.) INRA Production Animale 3, 103-119.

National Research Council (1994). Nutrient Requirements of Poultry, pp. 20, 27. Washington DC: National Academy Press.

Perez-Alba, L. M., Diaz-Arca, L. F., Cejas-Molina, M. A. \& Perez-Hernandez, M. (1990). Improving protein quality of maize-lupin diets with synthetic amino acids. Archivos de Zootecnia 39, 85-93.

Rani, N. \& Hira, C. K. (1993). Effect of various treatments on nutritional quality of faba beans (Vicia faba). Journal of Food Science and Technology 30, 413-416.

Ravindran, V. \& Blair, R. (1992). Feed resources for poultry production in Asia and the Pacific II. Plant protein sources. World's Poultry Science Journal 48, 205-231.

Reddy, N. R., Pierson, M. D., Sathe, S. K. \& Salunkhe, D. K. (1984). Chemical nutritional and physiological aspects of dry beans carbohydrates: a review. Food Chemistry 13, 25-68.

Sarwar, G., Sosulski, F. W., Bell, J. M. \& Bowland, J. P. (1978). Nutritional evaluation of oilseeds and legumes as protein supplements to cereals. In Nutritional Improvement of Food and Feed Protein, pp. 415-441 [Mendel Friedman, editor]. New York: Plenum Press.

SAS Institute Inc. (1990). SAS/STAT User's Guide, version 6, 4th ed. Cary, NC: SAS Inc.

Singh, U., Rao, P. V., Subrahmanyam, N. \& Saxena, K. (1993). Cooking characteristics, chemical composition and protein quality of newly developed genotypes of pigeonpea (Cajanus cajan, L.) Journal of the Science of Food and Agriculture 61, 395-400.

User Friendly Feed Formulation (1986). User Friendly Feed Formulation Program. The University of Georgia. van Barneveld, R. J., Batterham, E. S. \& Norton, B. W. (1993). Nutritional implication of heating protein concentrates on the digestibility and metabolism of lysine in growing pigs. In Recent Advances in Animal Nutrition in Australia, pp. 201-212 [D. J. Farrell, editor]. Armidale, NSW: UNE.

van der Poel, A. F. B. (1990). Effect of processing on antinutritional factors and protein nutritional value of dry beans (Phaseolus vulgaris L.). A review. Animal Feed Science and Technology 29, 179-208. 